\title{
Mechanical Properties of Urea Formaldehyde Particle Board Composite
}

\author{
Ejiogu Ibe Kevin ${ }^{1,}$, Odiji Mary Ochanya ${ }^{2}$, Ayejagbara Mosunmade Olukemi ${ }^{3}$, \\ Shekarri Tachye Ninas Bwanhot ${ }^{3}$, Ibeneme Uche $^{3}$ \\ ${ }^{1}$ Directorate of Research and Development, Nigeria Institute of Leather and Science Technology, Zaria, Nigeria \\ ${ }^{2}$ Department of Chemistry, Ahmadu Bello University, Samaru, Zaria, Nigeria \\ ${ }^{3}$ Department of Polymer Technology, Nigeria Institute of Leather and Science Technology, Zaria, Nigeria
}

Email address:

kevin.edu.research@gmail.com (E. I. Kevin)

${ }^{*}$ Corresponding author

\section{To cite this article:}

Ejiogu Ibe Kevin, Odiji Mary Ochanya, Ayejagbara Mosunmade Olukemi, Shekarri Tachye Ninas Bwanhot, Ibeneme Uche. Mechanical Properties of Urea Formaldehyde Particle Board Composite. American Journal of Chemical and Biochemical Engineering.

Vol. 2, No. 1, 2018, pp. 10-15. doi: 10.11648/j.ajcbe.20180201.12

Received: May 25, 2018; Accepted: June 7, 2018; Published: July 4, 2018

\begin{abstract}
Particle boards were prepared from sawdust and urea-formaldehyde resin (UFR) on compression moulding machine. The particleboards were produced at a compression temperature of $150^{\circ} \mathrm{C}$; a pressure of 10 tons was applied for 15 minutes. The amount of sawdust was kept constant at $20 \mathrm{~g}$ while UFR was varied from $30 \mathrm{ml}, 35 \mathrm{ml}, 40 \mathrm{ml}$ and $45 \mathrm{ml}$ respectively. The control sample (CS) was the 50ml UFR without any saw dust. The properties of the particleboards were tested using ASTM methods. The results showed that the properties of the particleboards are a function of the percentage composition of the binder (resin) and the filler (sawdust). The results showed that as the URF content increased from $30 \mathrm{ml}$ to $45 \mathrm{ml}$, the mechanical properties increased. The hardness increased from 88.6 shoreA to 99 shoreA while the percentage of water absorption decreased as the UFR content increased. The swelling thickness decreased as UFR content increased. The density increased as URF content increased.
\end{abstract}

Keywords: Urea Formaldehyde, Particle Board Composite, Sawdust, Mechanical Properties

\section{Introduction}

Particleboard has been defined as generic term for a panel manufactured from linger cellulosic materials, usually wood, primarily in the form of discrete pieces or particles, as distinguished from fibers, combined with a synthetic resin or other suitable binder and bonded together under heat and pressure in a hot press by a process in which the entire interparticle bond is created by the added binder, and to which other materials have been added during manufacture to improve certain properties [1].

Historically, the products from the light wood technology were very expensive and exclusive. They were used in the aeronautic field or in the automotive field. Over the time, the light wood products could be produced cheap, but with a better quality through increased efficiency in production processes, research, and development. This trend is very strong in the furniture industry [2-4].
Particleboard is cheaper, denser and more uniform than conventional wood and plywood and is substituted for them when appearance and strength are less important than cost. However, particleboard can be made more attractive by painting or the use of wood veneers that are glued onto surfaces that will be visible [5-7]. There are over a hundred particle board plants in operation today worldwide and particle board is one of the strongest reconstituted panel products and is considered as an ideal substitute to wood and plywood.

Urea-formaldehyde is a non-transparent thermosetting resin, made from urea and formaldehyde heated in the presence of a mild base such as ammonia or pyridine. It is characterized by high tensile strength, flexural modulus, and heat distortion temperature, low water absorption, mould shrinkage, high surface hardness, elongation at break, and volume resistance [8-10]. It is used in many manufacturing

Processes. Examples include decorative laminates, textiles, paper, foundry sand moulds, wrinkle-resistant fabrics, cotton 
blends, rayon, corduroy, etc. It is also used to glue wood together. Urea formaldehyde was commonly used when producing electrical appliances casing (e.g. desk lamps).

Urea-formaldehyde (UF) resin is extensively used as a binder adhesive for the production of wood-based panels such as medium density fiberboard, particleboard (PB) and hardwood plywood for interior uses. UF resin is an excellent adhesive with features such as virtually colorless glue lines, low price, mold and fungi resistance, and ease of handling (e.g.; mixing, applying and cleaning). UF resin can be successfully bonded with most species of wood in many combinations $[11,12]$. However, formaldehyde emission is the main disadvantage property of the UF resin. The lower formaldehyde/urea $(\mathrm{F} / \mathrm{U})$ molar ratio, the lower the content of free formaldehyde in the UF resins. The formaldehyde emission of UF resin has been declining as a result of new resins and resin technologies [13].

The use of Urea-formaldehyde for the production of particle board and as an adhesive resin has been widely reported due to its high reactivity, good performance, and low price [14]. The use of Urea-Formaldehyde for the production of particle board using saw dust has also been reported [15]. Studies on the use of buckwheat stalk in particleboards bonded with urea-formaldehyde resin adhesive have been reported $[16,17]$. It has reported that one of the major difficulties in the processing of wood-based particle boards with urea-formaldehyde is that urea-formaldehyde is a volatile gas with strong odor [18-20].

Production of particleboards, as stated earlier, involves the use of a binder (resin). A large amount of binder is being used in particleboard industry for the production of highquality products. The binder accounts for up to $32 \%$ of manufacturing cost in the glue-wood composite industry. Various types of binders have been used in the manufacture of particleboards and they are classified as satisfying interior or exterior use requirements primarily on the basis of their response to moisture and/or temperature. At present, the principal ones are formaldehyde condensation polymers, such as Urea-formaldehyde (UF), Phenol-formaldehyde (PF), Phenol-resorcinol formaldehyde (PRF), Melamineformaldehyde (MF) and their derivatives (i.e. modified formaldehyde condensation polymers). Others include; isocyanate adhesive, gypsum, nitrogenous modified amylaceous binder, magnesia, etc. The relatively low cost and proven performance of phenol-formaldehyde and ureaformaldehyde resins have made them the most important adhesive systems for composite wood products. These two resins are formed by step-growth (condensation) polymerization reaction of formaldehyde $\left(\mathrm{CH}_{2} \mathrm{O}\right)$ with phenol $\left(\mathrm{C}_{6} \mathrm{H}_{5} \mathrm{OH}\right)$ and urea $\left(\mathrm{H}_{2} \mathrm{NCONH}_{2}\right)$ respectively

Urea is a colorless and odorless crystalline compound, $\mathrm{CO}\left(\mathrm{NH}_{2}\right)_{2}$, with a melting point of $132.7^{\circ} \mathrm{C}$, also known as carbamide. It is found abundantly in the urine of humans and other mammals. In lesser quantities, it is present in the blood, liver, lymph, and serous fluids and is found in the excrement of fish and many other lower animals. Urea is produced mostly in the liver as the end product of protein metabolism.
The nitrogen in urea, which constitutes most of the nitrogen in the urine, is produced mainly from food protein, but part comes from the breakdown of body cells. Urea is also present in various fungus molds as well as in the leaves and seeds of numerous legumes and cereals. The compound is soluble in both water and alcohol and is slightly soluble in ether. Urea is prepared synthetically by the Wohler synthesis, which was devised in 1828 by the German Chemist Friedrich Wohler.

$$
\mathrm{CO}_{2}+2 \mathrm{NH}_{3} \rightarrow \mathrm{NH}_{3} \mathrm{CONH}_{3}+\mathrm{H}_{2} \mathrm{O} \leftrightarrow \mathrm{H}_{2} \mathrm{NCOONH}_{4}
$$

Due to its high nitrogen content, commercially prepared urea is used in the manufacture of agricultural fertilizers. Urea is also employed as a stabilizer in nitrocellulose explosives and is a basic constituent of synthetically prepared resins. Urea-formaldehyde (UF) resins are composed of molecules that cross-link into clear, hard plastics. Properties of UF resins are similar to the properties of phenolic resins. As the names imply, these resins are formed by condensation reactions between urea $\left(\mathrm{H}_{2} \mathrm{NCONH}_{2}\right)$ and formaldehyde $\left(\mathrm{CH}_{2} \mathrm{O}\right)$. Two main steps are recognized in the reaction of formaldehyde with amino compounds to form useful resins.

\section{Materials and Methods}

\subsection{Materials}

Sawdust, Glasswares, Thermostat hot plate, Fume cupboard, Magnetic stirrer, Metal and Mould plate, Compression moulding (20 tonnes) machine. Digital $\mathrm{pH}$ Meter, Top loading balance, spatula, and thermometer.

$400 \mathrm{ml}$ of $40 \% \mathrm{w} / \mathrm{v}$ formaldehyde solution (M \& B laboratory grade), Urea (200mg M \& B, Ammonia (15ml) solution, Ammonium Chloride.

\subsection{Methods}

\subsubsection{Processing of Sawdust}

The sawdust was obtained from a sawmill in Samaru, Zaria, Nigeria. It was first dried in the sun for about $72 \mathrm{hrs}$, ground and sieved to obtain uniformed particle size saw dust using a $72 \mu \mathrm{m}$ sieve.

\subsubsection{Laboratory Synthesis of Urea Formaldehyde Resin}

This was done by the condensation reaction of formaldehyde with urea in the ratio of 2.0:1.0. $400 \mathrm{ml}$ of $40 \%$ aqueous solution of formaldehyde was measured into a clean dried Pyrex $500 \mathrm{ml}$ beaker standing on a thermostat hot plate and the solution was stirred vigorously in a fume cupboard for 5minuites. $200 \mathrm{~g}$ of Urea was gradually added, followed by $15 \mathrm{ml}$ of ammonia solution, the mixture was continuously stirred with a magnetic stirrer for one hour at a temperature of $65^{\circ} \mathrm{C}$. The solution obtained was then concentrated by heating the solution at a temperature slightly above $65^{\circ} \mathrm{c}$ for $5 \mathrm{hrs}$ to evaporate the water content, $\mathrm{pH}$ was maintained at 8 . The concentrate was allowed to cool at room temperature to produce a viscous liquid.

\subsubsection{Resinification and Formulation Stage}

A constant weight of the sawdust was added to the 
synthesized Urea-Formaldehyde solution and thoroughly mixed using an electric mixer. The impregnated moisture material was then poured into a mould with dimensions (120mm length, $60 \mathrm{~mm}$ width, and $2 \mathrm{~mm}$ thickness) containing aluminum foil. The mould was then placed in a compression moulding machine at a pressure of 10 tonnes and temperature of $150^{\circ} \mathrm{C}$ for 15 minutes. The procedure was carried out for $30,35,40$, and $45 \mathrm{ml}$ of urea formaldehyde resin with the constant weight of the filler (sawdust). The particleboard samples produced were allowed to cool at room temperature, and their mechanical properties determined.

NOTE:-CS is the control sample with no filler content and $50 \%$ UF Content.

\subsubsection{Shore Hardness}

Hardness was done according to ASTM D 2240, which is a measure of the resistance of a material to the penetration of a needle under a defined spring force. It is determined as a number from 0 to 100 on the scales A or D. The higher the numbers, the higher the hardness. The letter A is used for flexible types and the letter D for rigid types. Measurements were performed at room temperature. Shore A hardness scale was used and the average of 3 hardness values was taken.

\subsubsection{Water Absorption}

This was done using the kubrelka apparatus at room temperature. The test was carried out by weighing the specimens (20mm length, $10 \mathrm{~mm}$ width, and $2 \mathrm{~mm}$ thickness) before and after soaking in water for $24 \mathrm{hrs}$.

$$
\mathrm{Q}=\mathrm{W}_{2}-\mathrm{W}_{1} / \mathrm{W}_{1} \times 100
$$

\subsubsection{Thickness Swell}

The thickness swell test was carried out by measuring the thickness of the specimens before and after 24 hours in water using the Thickness gauge with serial No 82; all were set at room temperature. The ratio of the difference in thickness to the original thickness of the specimens expressed as a percentage is the percentage thickness swell of the sample.

\subsubsection{Density}

The density of each of the specimens was obtained by dividing the weight of each specimen with its corresponding calculated volume. Their weights were obtained using analytical-weighing balance, while the volume was obtained by multiplying their respective measured Length, width, and Thickness.

$$
\rho=m / v
$$

In Equation 3, $\rho=$ density. $m=$ mass of the specimens in grams. $\mathrm{v}=$ volume in $\mathrm{cm}^{3}$.

In Equation 2, $\mathrm{Q}=$ percent water absorption, $\mathrm{W}_{1}=$ initial weight, $\mathrm{W}_{2}=$ Final Weight

\section{Results and Discussion}

\subsection{Shore Hardness}

Shore hardness is a measure of the resistance of a material to the penetration of a needle under a defined spring force, which gave an indication of the hardness of the particle board. Figure 1 showed that the shore hardness of the UF particleboard increased from the particleboard samples of 88.6, 90.0, 91.0, 92.0 and $99.0 \%$ respectively. The higher the numbers, the higher the hardness of the particle board at room temperature.

Table 1. Result for Hardness Test.

\begin{tabular}{llllll}
\hline UF (ml) & Filler (sawdust) $\mathbf{g}$ & $\mathbf{1}^{\text {st }}$ test & 2nd & $\mathbf{3}^{\text {rd }}$ & Average ShoreA \\
\hline 30 & 20 & 89 & 88 & 89 & 88.6 \\
35 & 20 & 91 & 90 & 89 & 90.0 \\
40 & 20 & 92 & 91 & 90 & 91.0 \\
45 & 20 & 91 & 93 & 92 & 92.0 \\
CS & - & 95 & 95 & 94 & 99.0 \\
\hline
\end{tabular}

\subsection{Water Absorption}

The results showed that there was a reduction in water absorption of $16.67 \%, 10.00 \%, 6.95 \%, 5.55 \%$ respectively as the quantity of UF utilized in the particle board increased, the CS showed little or no affinity for water. This was as a result of the hydrophobic nature of UF brought about by the strong intermolecular cohesive bonding within the molecule of the UF resin which prevented water from penetrating the UF. However, as filler was introduced into the UF matrix, the hydrophobic nature was reduced due to the high affinity of the organic filler to water (hydrophilic), and this increased as the amount of UF resin utilized in the composite reduced.
The response of a particleboard to humidity is a function of the degree of water absorption or ability to resist moisture. It is a sample rather than material property, and as such, it depends on the composition and processing history of the sample.

This is not unexpected because principally condensation polymers are susceptible to degradation due to the effect of water, filler content, and multiple exposures such as moisture and heat can result in accelerated deterioration [21, 22, 23]. This is an indication that the cohesive and binding forces of the UF resin are not stronger and less sustainable, even at elevated temperature [24-26], the present work supports this statement as shown in the result. 
Table 2. Results of Water Absorption

\begin{tabular}{lllll}
\hline UF $(\mathbf{m l})$ & Filler (sawdust) $\mathbf{g}$ & Weight $(\mathbf{g})$ & volume of water absorbed $(\mathbf{m l})$ & Percentage of water absorbed \% \\
\hline 30 & 20 & 1.2 & 0.2 & 16.67 \\
35 & 20 & 1.9 & 0.19 & 10.00 \\
40 & 20 & 2.3 & 0.16 & 6.95 \\
45 & 20 & 2.7 & 0.15 & 5.55 \\
CS & - & 2.9 & - & - \\
\hline
\end{tabular}

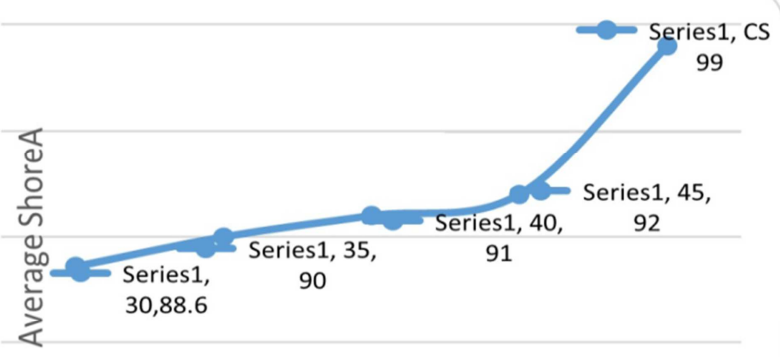

UF Composition

Figure 1. Hardness versus UF Composition

\subsection{Thickness}

Figure 3 showed the graphical illustration of the results of the thickness swelling of the particleboards showed that the degree of thickness swelling; a measure of the dimensional stability of particleboards in a humid environment is a function of the composition and the prevailing temperature. At room temperature, the particleboards exhibited highest thickness swell of $0.004 \mathrm{~mm}, 0.004 \mathrm{~mm}, 0.003 \mathrm{~mm}, 0.002 \mathrm{~mm}$ and $0.000 \mathrm{~mm}$ with the UF there was no significant change in their original thickness as shown in Figure 3, implying that the particleboards had less dimensional stability at the room temperature and the resin composition. This could be attributed to its weak and relatively less stable cohesive and adhesive forces.

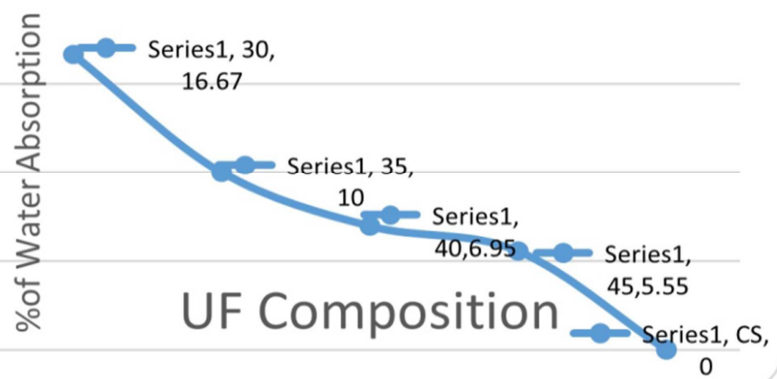

Figure 2. Percent Water Absorption vs. UF Composition.

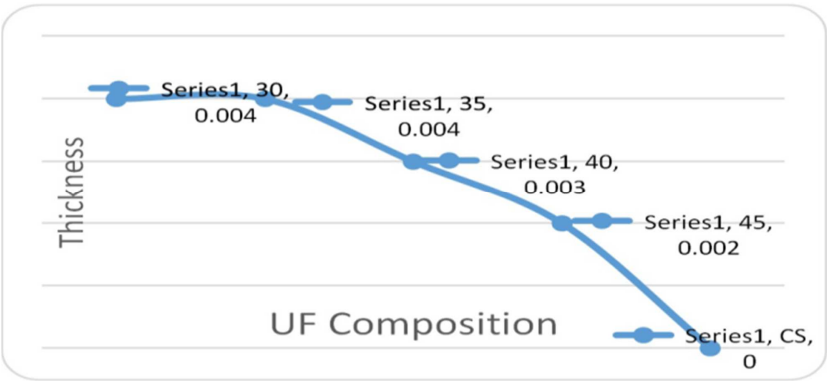

Figure 3. Thickness vs. UF Composition

Table 3. Results of Swelling Thickness Test.

\begin{tabular}{lllll}
\hline UF $(\mathbf{m l})$ & Filler (sawdust) $\mathbf{g}$ & Thickness before swelling & Thickness after swelling & Changes in Thickness (mm) \\
\hline 30 & 20 & 2.006 & 2.010 & 0.004 \\
35 & 20 & 2.004 & 2.008 & 0.004 \\
40 & 20 & 2.003 & 2.006 & 0.003 \\
45 & 2.000 & 2.002 & 0.002 \\
CS & - & 2.000 & 2.000 & 0.000 \\
\hline
\end{tabular}

\subsection{Density}

The density of material connotes its mechanical properties. Figure 4 Shows that the density of the UF particleboard decreased from the particleboard samples of $0.00065,0.00104,0.00126,0.00148$ and 0.00159 , However, at the $45 \%$ UF resin composition, there was a significant increase in density. UF particleboards were found to have a lower density due to weaker compaction force that exists in the UF particleboards. However, at $40 \%$ and $45 \%$ UF resin composition, the UF particleboards are slightly denser.

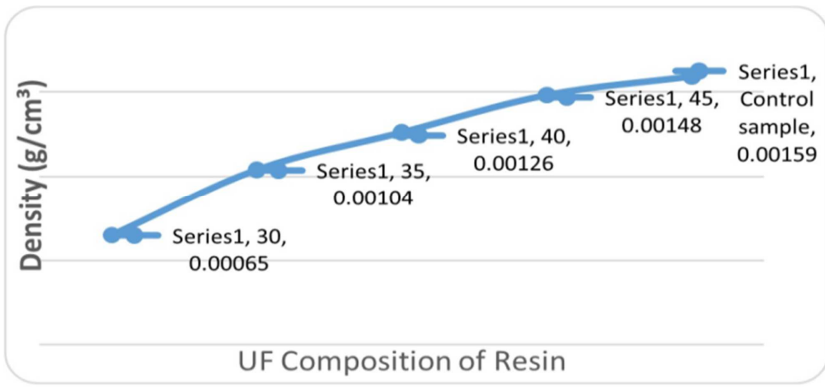

Figure 4. Density vs. UF Composition. 
Table 4. Results of Density Test.

\begin{tabular}{lll}
\hline UF $(\mathbf{m l})$ & Filler (sawdust) $\mathbf{g}$ & Density $\left(\mathbf{g} / \mathbf{c m}^{3}\right)$ \\
\hline 30 & 20 & 0.00065 \\
35 & 20 & 0.00104 \\
40 & 20 & 0.00126 \\
45 & 20 & 0.00148 \\
CS & - & 0.00159 \\
\hline
\end{tabular}

\section{Conclusion}

The property of the particleboard is a function of the percentage composition of the components. This implies that the properties of the particleboard depend on the resin-filler ratio. Consequently, variation in the percentage composition alters the properties of the particleboard.

Particle boards can be produced from sawdust using ureaformaldehyde as a binder

Urea-formaldehyde particleboards have less ability to resist water penetration. Hence, UF particleboards have less dimensional stability. As a result, UF particleboards would not have better application in the moist or humid environment.

Particle boards produced using more volume of UF are more dimensionally stable as evident in their smaller values of water absorption and thickness swelling compared with the other samples of a small quantity of the UF.

The results show that the resin-sawdust ratio significantly influenced the water absorption, thickness swelling, hardness and density

UF resin imparted poor mechanical properties to the particleboards. As a result, the PF particleboard is said to exhibit poor resistance to deformation. Therefore, the UF particleboards would be less durable, less tough and have less ability to resist abrasion as reported by [27, 28, 29].

UF particleboards are less expensive to produce as one of the major components (Urea) is readily and cheaply available, as compared to PF Particleboards [30-33].

\section{Recommendations}

1. Modification of catalytic processes that brings or produce less reactive resins with environmental vapour.

2. The temperature and pressure at which the composite made should be slightly adjusted to analyze whether this parameter can contribute towards the production of good water repellant particleboard which can commercially viable.

3. Particleboards made from sawdust can suitably be used for making furniture, door, and other wood products so as to reduce the pressure on solid board and the natural forest.

4. Polyethylene waste can be appropriately used as an adhesive alternative for formaldehyde-based resins in particle board manufacturing so as to eliminate the health effects formaldehyde-based resins cause to humans.

\section{Conflict of Interest}

The Authors declared no conflict of interest in this research work.

\section{References}

[1] Rocket. F. H., Encyclopaedia of Science and Technology 8th edition, Volume 4, P 257 (McGraw-Hill Inc 1997).

[2] Brady, George S.; Clauser, Henry R.; Vaccari A., John. Materials Handbook (14th ed.). (New York, NY: McGraw-Hill 1997).

[3] Yong-Sung Oh Mohd Ariff Jamaludin Evaluation of rapeseed stalk particleboard bonded with laboratory-made ureaformaldehyde resinCiência Florestal, Santa Maria, v. 25, n. 2, 2015 p. 515-521.

[4] Mamza. P. A. P. and Shadrach, K., The mechanical properties of urea formaldehyde particle boards International Journal of Pure and Applied, 2 (2), 2008. 15-21.

[5] Yong-S. O and Sung. S, Use of buckwheat stalk in particleboard bonded with urea-formaldehyde resin adhesive, Cellulose Chemistry andTechnology, 46 (9-10), 2012. 643-647.

[6] Hofstrand. A. D, Mosleni. A. A, Garcia. J. F, Curing Characteristics of wood particles from nine northern Rocky Mountains species mixed with Portland cement, Forestry Production Journal 34 (7), 1984. 56-61.

[7] Aisien F. A, Amenaghawon AN, Bienose KC. Particle boards produced from cassava stalks: Evaluation of physical and mechanical properties. S Afr J Sci. 2015; 111 (5/6), Art. \#2014-0042, 4 pages. http://dx.doi.org/10.17159/ sajs.2015/20140042

[8] Duku M. H, Gu S, Hagan EB. A comprehensive review of biomass resources and biofuels potential in Ghana. Renew Sust Energy Rev. 2011; 15 (1): 404- 415. http://dx.doi.org/10.1016/j.rser.2010.09.033

[9] Amenaghawon N. A, Aisien FA, Ogbeide SE. Bioethanol production from pretreated cassava bagasse using combined acid and enzymatic hydrolysis. University of Benin J Sci Technol. 2013; 1 (2): 48-53.

[10] Paul A. P Mamza, Emmanuel C. Ezeh, E. C. Gimba, David Ebuka Arthur. Comparative Study Of Phenol Formaldehyde And Urea Formaldehyde Particleboards From Wood Waste For Sustainable Environment. International Journal of Scientific \& Technology research. 2014 volume 3, issue 9.

[11] Mamza, P. A. P. Shedrach, K. (2008). The Mechanical Properties of Urea-formaldehyde particleboards. International Journal of Pure and Applied Sciences, 2 (2) 15-21.

[12] Mamza, P. A. P. Aliu, A. Muhammed, R. A. (2010). The effects of iron filling on some mechanical and physical properties of sawdust particleboard. Nigerian Journal of Basic and Applied Science, 18 (1): 112-119.

[13] Adajineh, F., 2008, "Production of particleboard composite from sugarcane bark and Baggasse", Unpublished Research project, Chemical Engineering Department, A. B. U, Zaria. Nigeria.

[14] Deppe, H. J, and Ernst, K, 1986, "Reducing Particleboard Pressing Time", An Exploratory study, U.S Dept. of Agriculture Forest Service, Madison, 3-14 USA. 
[15] Deka, M. and Saikia, C. N, 2000, "Effects of Amino Resin Treatment on Dimensional Stability, Bio Researches Technology 73, 179-181.

[16] Mosesson, J. G, 1980, "The processing and use of straw as constructional Material". Conservation and reserving 3: 369412 .

[17] Wang, D. and Sun, X. N. 2002, "Low-density particleboard from wheat Straw and corn pith" Industrial crops and products. $15,47-50$.

[18] www.niir.org/books/book/zb, 2005, "The Complete Technology Book on Wood and Its Derivative". National Institute of IndustrialResearch.

[19] Bodig, J, and Jayne, B. A (1982) Mechanics of wood and wood composite, Van Nostrand Reinhold Company Inc, New York.

[20] Cartyle, A. A.; McGee, L. B., and McLean, R. A (1956) Wood Particleboard Handbook, School of Engineering, North Carolina State College Raleigh, N. C. 57.

[21] Cope, D. (1960). Cope's Plastics Book, The GoodheartWillcox Co. Inc Publishers, Chicago, USA.

[22] Davis, G. A., and Dhingra, R. (2001). Particleboard and Medium-density Fibreboard, the University of Centre for Clean Products and Clean Technologies Choose Green Report. Tennessee, Washington D. C.

[23] Eom, Y. G.; Kim, S.; Baek, I-C. and Kim, H-J. (2005). Comparison of Formaldehyde Emission of Wood-Based Panels With Different Adhesive hardener Combinations by Gas Chromatography and Standard Methods, Mokchae Konghak.

[24] FAO (1950). Food and Agriculture Organization: Forest policy, law, and Administration, FAO Publications.
[25] Frederick, T. W. and Norman, E. W. (2004). Natural fibers, plastics, and composites, Springer Publications.

[26] Grainger, A. (1993). Controlling Tropical Deforestation, Earthscan Publication Ltd, London.

[27] Kent and Riegel's Handbook of Industrial Chemistry and Biotechnology, 12 Ed. Vol 1 Springer Science+ Business Media, LLC, 233 Spring Street, New York, NY 10013, USA.

[28] Kollmann, F. F. P.; Kuenzi, E. W., and Stamm, A. J. (1975) Principles of wood science and technology, Volume II: Woodbased materials, Springer-Verlag, Berlin, Heidelberg, New York.

[29] Loh, Y. W.; H`ng, P. S.; Lee, S. H.; Lum, W. C. and Tan, C. K. (2010). Properties of Particleboard Produced from Admixture of Rubberwood and Mahang Species. Asian Journal of Applied Sciences, 3: 310-316.

[30] Tamakloe, W. (2000). State of Ghana's environment, Challenges of Compliance and enforcement, Ghana Environmental Protection Agency.

[31] Wagner, M. R.; Cobbinah, J. R., and Bosu, P. P., (2008). Forest Entomology in West Tropical Africa, $2^{\text {nd }}$ Ed., Springer Publishers, Netherland.

[32] Haygreen, G. J. and Bowyer J. L. (1996). Forest products and wood science: an introduction. $3^{\text {rd }}$ ed. Ames: Iowa State University Press.

[33] Hoadley, R. B. (2000). Understanding Wood, A Craftsman's Guide Wood Technology The Taunton Press, Newtown. 